Qiro'ah| Jurnal Pendidikan Agama Islam

Vol. 11 No. 12021 https://ejurnal.iiq.ac.id/index.php/qiroah

P-ISSN: 2085-0115 E-ISSN: 2656-3819

DOI: https://doi.org/10.33511/qiroah.v11n1.76-94
Diterima $\quad: 14$ Mei 2021

Direvisi : 21 Mei2021

Disetujui : 14 Juni 2021

Diterbitkan : 12 Juni 2021

\title{
KEPEMIMPINAN KEPALA SEKOLAH DALAM MENINGKATKAN MUTU PENDIDIKAN ISLAM
}

\author{
Syifa Nur Izzati Zahro, Siti Shopiyah \\ Institut Ilmu Al-Qur`an (IIQ) Jakarta \\ syifaizzati99@gmail.com, s.hopiyah@iiq.ac.id
}

\begin{abstract}
Abstrack
The background of the authors doing research is that in 2019 the principal got second nomination as head of the school to perform grades. SD Islamic Plus As-Sa'adatain has many achievements in Islamic fields and excelled within Islamic education. So reaserchers want to know the principal's leadership style and the headmaster's efforts to improve Islamic education. The purpose of research is to know the headmaster's leadership style in improving Islamic education at SD Islamic Plus As-Sa'adatain Cinere Depok. The method of research that the writer uses is qualitative research wtih a descriptive approach. This is because the writer described or presented a complete picture of the pricipal's leadership style in improving Islamic education at SD Islamic Plus As-Sa'adatain Cinere Depok. Research shows that the leadership style used by the Islamic primary school principal plus ASAs-Sa'adatain is used as a favor to democratic leadership styles. The headmaster principal of SD Islam Plus As-Sa'adatain in solving problems and making decisions is always done with deliberation. The headmaster of principle leading (teachers, staff, students) is that the principal does not depend on formal, rigid power, being casual, firm, flexible, dicipline not too formal but is still responsible and able to mentor. The way headmaster Islamic elementary school plus As-Sa'adatain communicates with subbordinates (teachers, staff and students) of good, relaxed, courteous, polite, warm, harmonious, firm, depply communicative, and authoritative. The quality of Islamic education at Islamic SD Islam Plus As-Sa'adatain is already good, from its planning, its process, and its results.
\end{abstract}

Keywords: The Principal's Leadership Style, The Quality of Islamic Education.

\begin{abstract}
Abstrak
Latar belakang penulis melakukan penelitian adalah pada tahun 2019 kepala sekolah mendapatkan nominasi kedua sebagai kepala sekolah berprestasi tingkat kecamatan. SD Islam Plus AsSa'adatain memiliki banyak prestasi bidang ke-Islaman dan unggul dalam pendidikan Islam. Sehingga peneliti ingin mengetahui gaya kepemimpinan kepala sekolah dan upaya kepala sekolah dalam meningkatkan mutu pendidikan Islam. Tujuan penelitian adalah untuk mengetahui gaya kepemimpinan kepala sekolah dalam meningkatkan mutu pendidikan Islam di SD Islam Plus As-Sa'adatain Cinere Depok. Metode Penelitian yang penulis gunakan adalah penelitian kualitatif, dengan pendekatan deskriptif. Hal ini dikarenakan penulis mendeskripsikan atau menyajikan gambaran lengkap tentang Gaya Kepemimpinan Kepala Sekolah dalam meningkatkan mutu pendidikan Islam di SD Islam Plus As-Sa'adatain Cinere Depok. Hasil penelitian menunjukkan bahwa gaya kepemimpinan yang digunakan kepala sekolah SD Islam Plus As-Sa'adatain cenderung kepada gaya kepemimpinan yang Demokratis. Kepala sekolah SD Islam Plus As-Sa'adatain dalam memecahkan masalah dan mengambil keputusan selalu dilakukan dengan musyawarah. Kepala sekolah dalam menggerakkan/memimpin bawahan (guru, staf, siswa) yaitu kepala sekolah tidak bergantung pada kekuasaan yang formal ketat dan kaku, bersikap santai, tegas, fleksibel, disiplin tidak terlalu formal tetapi tetap bertanggung jawab serta dapat mengayomi. Cara kepala sekolah SD Islam Plus As-Sa'adatain dalam berkomunikasi dengan bawahan (guru, staf dan siswa) yaitu baik, santai, ramah, sopan, santun, hangat, harmonis, tegas, sangat komunikatif, dan berwibawa. Mutu pendidikan Islam di SD Islam Plus As-Sa'adatain sudah baik, dari perencanaannya, prosesnya dan juga hasilnya.
\end{abstract}

Kata Kunci: Gaya Kepemimpinan Kepala Sekolah, Mutu Pendidikan Islam. 


\section{PENDAHULUAN}

Pendidikan adalah usaha sadar dan terencana untuk mewujudkan suasana belajar dan proses pembelajaran agar peserta didik secara aktif mengembangkan potensi dirinya untuk memiliki kekuatan spiritual keagamaan, pengendalian diri, kepribadian, kecerdasan, akhlak mulia serta keterampilan yang diperlukan dirinya, masyarakat, bangsa dan negara. ${ }^{1}$ Terwujudnya sekolah yang efektif mensyaratkan bahwa adanya kepemimpinan intruksional yang kuat, perhatian yang jelas pada hasil belajar, penghargaan peserta didik yang tinggi, lingkungan yang baik serta pengawasan tingkat prestasi.

Keberhasilan sebuah lembaga pendidikan sangat ditentukan oleh peran kepemimpinan kepala sekolah. Karena kepala sekolah sebagai pemimpin pada lembaganya, maka kepala sekolah harus mampu membawa lembaga ke arah tercapainya tujuan yang telah ditentukan. Kepala sekolah harus mampu melihat adanya perubahan terhadap regulasi pendidikan dan kehidupan globalisasi.

Dalam kepemimpinan dikenal gaya kepemimpinan yang biasanya digunakan pemimpin dalam mempengaruhi bawahan. Menurut Thoha, gaya kepemimpinan merupakan norma perilaku yang digunakan oleh seseorang pada saat orang tersebut mencoba memengaruhi perilaku orang lain seperti yang ia lihat. Jadi dengan gaya kepemimpinan yang tepat kepala sekolah dapat memengaruhi dan memotivasi guru agar mencapai tujuan tertentu. ${ }^{2}$

Kualifikasi dan standarisasi kompetensi kepala sekolah diatur dalam Peraturan Menteri Pendidikan Nasional Republik Indonesia no. 13 tahun 2007 yang mengatakan bahwa kepala sekolah bertanggung jawab terhadap keberhasilan proses pembelajaran di sekolah dan merupakan salah satu komponen pendidikan yang berpengaruh dalam meningkatkan kinerja guru. Kepala sekolah bertanggung jawab atas penyelenggaraan kegiatan pendidikan, administrasi sekolah, pembinaan tenaga kependidikan lainnya, dan pendayagunaan serta pemeliharaan sarana dan prasarana di mana ia bertugas. ${ }^{3}$

Peningkatan Mutu Pendidikan Islam merupakan salah satu keharusan lembaga pendidikan melakukan perubahan dan pengembangan agar bisa menjawab dan memenuhi kebutuhan masyarakat. Untuk itu diperlukan seorang pemimpin yang mampu membawa perubahan dalam dunia pendidikan serta terus mengembangkan inovasi-inovasi baru dalam mengembangkan lembaga pendidikan.

Untuk meningkatkan kinerja guru dan mutu pendidikan dibutuhkan kompetensi kepemimpinan kepala sekolah yang profesional. Peran kepala sekolah dalam sebuah institusi bukan hanya sekedar seorang pemimpin, tetapi juga berfungsi sebagai akumulator, konseptor, serta manajer. Maka kepala sekolah

\footnotetext{
${ }^{1}$ Syaiful Bahri Djamarah, Strategi Belajar Mengajar, (Jakarta: Rineka Cipta, 1995) hlm. 1

${ }^{2}$ Hendarman, Revolusi Kinjerja Kepala Sekolah, (Jakarta: PT. Indeks, 2015) hlm, 17.

${ }^{3}$ Peraturan Menteri Pendidikan Republik Indonesia Nomor 13 Tahun 2006 (Jakarta: 2007)
} 
Qiro'ah| Jurnal Pendidikan Agama Islam

Vol. 11 No. 1 2021| https://ejurnal.iiq.ac.id/index.php/qiroah P-ISSN: 2085-0115 E-ISSN: 2656-3819

DOI: https://doi.org/10.33511/qiroah.v11n1.76-94
Diterima

Direvisi

Disetujui

Diterbitkan
: 14 Mei 2021

: 21 Mei2021

: 14 Juni 2021

: 12 Juni 2021

bukan saja memerankan fungsi sebagai sosok yang bisa menggerakkan, memengaruhi dan memaksa bawahannya untuk melaksanakan tugas organisasi, namun juga bertanggung jawab pada kontribusi masing-masing demi efektivitas dan efisiensi kelangsungan pendidikan. Sehingga seorang kepala sekolah harus mampu menentukan kapan harus bersikap otoriter, serta demokratis. ${ }^{4}$

Pada waktu penulis melaksanaan Pengenalan Lapangan Persekolahan 1 (PLP 1) yang dilaksanakan di SD Islam Plus As-Sa'datain Cinere, dari hasil wawancara dan observasi selama 2 minggu penulis tertarik untuk meneliti kepemimpinan kepala sekolah tersebut. Sekolah ini memiliki kepala sekolah yang aktif, cerdas, visioner, bertanggung jawab dalam memimpin sehingga perkembangan sekolah terus lebih baik setiap tahunnya. Sekolah ini memang baru berdiri pada tahun 2008, tetapi prestasi dan mutu pendidikan di sana tidak kalah bagus dengan sekolah yang sudah berdiri lebih lama.

Selain itu banyak prestasi yang telah diraih siswa-siswi SD Islam Plus AsSa'datain baik di bidang Akademik maupun non Akademik. Prestasi yang diraih setiap tahun di antaranya Tahfidz Juz 30, MTQ Pelajar Cabang Tahfidz Putra dan Tilawah Putri, juga mendapatkan pengahargaan dari pemerintah kota Depok karena telah menyelenggarakan program Go Green, dan masih ada beberapa prestasi yang lainnya lagi. Ciri khas SD Islam Plus As-Sa'datain ini yaitu apabila ada siswa yatim dan dhu'afa maka biaya sekolahnya mulai dari kelas 1 sampai kelas 6 di tanggung penuh oleh pihak sekolah.

Adapun usaha kepala sekolah dalam meningkatkan mutu pendidikan SD Islam Plus As-Sa'datain, kepala sekolah juga mengadakan pembinaan atau pelatihan rutin setiap tahunnya untuk meningkatkan profesionalitas guru sekolah. Hal tersebut merupakan salah satu cara kepemimpinan kepala sekolah dalam meningkatkan mutu pendidikan. Inilah peran kepala sekolah dalam mengambil keputusan dalam perbaikan kualitas sekolah.

\section{METODE PENELITIAN}

Jenis penelitian yang digunakan adalah penelitian kualitatif (qualitative research), yaitu penelitian untuk menjawab permasalahan yang memerlukan pemahaman secara mendalam dalam konteks waktu dan situasi yang bersangkutan, dilakukan secara wajar dan alami sesuai dengan kondisi objektif di lapangan tanpa adanya manipulasi, serta jenis data yang dikumpulkan terutama data kualitatif. ${ }^{5}$ Adapun alasan menggunakan metode ini adalah karena ingin menggali, mengamati, atau mencari data-data yang lebih akurat terkait dengan penelitian tersebut.

\footnotetext{
${ }^{4}$ Hendarman, Revolusi Kinjerja Kepala Sekolah, (Jakarta: PT. Indeks, 2015) hlm, 6

5 Zainal Arifin, M.Pd, Penelitian Pendidikan : Metode dan Paradigma Baru, (Bandung: PT Remaja Rosdakaya, 2014), hlm.29
} 
Qiro'ah| Jurnal Pendidikan Agama Islam

Vol. 11 No. 1 2021| https://ejurnal.iiq.ac.id/index.php/qiroah P-ISSN: 2085-0115 E-ISSN: 2656-3819

DOI: https://doi.org/10.33511/qiroah.v11n1.76-94
Diterima

Direvisi

Disetujui

Diterbitkan
: 14 Mei 2021

: 21 Mei2021

: 14 Juni 2021

: 12 Juni 2021

Pendekatan yang digunakan dalam penelitian ini adalah pendekatan deskriptif. Pendekatan deskriptif adalah rangkaian proses pengumpulan data, menganalisis data, menginterprestasikan data, serta menarik kesimpulan yang berkenaan dengan data tersebut. Peneliti menggunakan pendekatan ini dikarenakan akan mendeskripsikan tentang peran kepemimpininan kepala sekolah SDI Plus As-Sa'datain dalam meningkatkan mutu pendidikan Islam.

Penelitian kualitatif lebih menekankan pada peneliti sebagai key instrument. Peneliti harus mampu mengungkapkan fenomena yang unik di lapangan dengan mengerahkan segenap fungsi indrawinya. Peneliti harus dapat diterima oleh responden dan lingkungannya agar mampu mengungkap data yang tersembunyi melalui tutur bahasanya, bahasa tubuhnya, perilakunya, maupun ungkapan-ungkapan yang berkembang dalam lingkungan sekitar responden. ${ }^{6}$

Dengan demikian, dapat disimpulkan bahwa penelitian kualitatif adalah penelitian yang menghasilkan data deskriptif subyek dan informan yang telah ditentukan dan disajikan dengan mendeskripsikan data selama penelitian berlangsung tanpa adanya perhitungan statistik.

\section{HASIL DAN PEMBAHASAN}

Hasil penelitian yang penulis lakukan di SD Islam Plus As-Sa'adatain mengenai Kepemimpinan Kepala Sekolah dalam Meningkatkan Mutu Pendidikan Islam di SD Islam Plus As-Sa'adatain adalah sebagai berikut:

\section{Gaya Kepemimpinan Kepala Sekolah SD Islam Plus As-Sa'adatain}

Kepala sekolah SD Islam Plus As-Sa'adatain saat ini yaitu Umi $\mathrm{Hj}$. Suryani, S.Ps.I. Kepemimpinan yang sudah berjalan selama kurang lebih 8 tahun, beliau menjabat menjadi kepala sekolah sejak tahun 2013-2018 periode pertama dan 2018- sekarang menjabat periode kedua. Beliau mendapatkan nominasi kedua sebagai kepala sekolah berprestasi tingkat kecamatan pada tahun 2019.

Nurkholis menyatakan dalam bukunya, gaya kepemimpinan adalah suatu perilaku konsisten yang ditunjukkan oleh pemimpin dan diketahui oleh pihak lain pada saat pemimpin berusaha mempengaruhi kegiatan-kegiatan orang lain. Gaya kepemimpinan merupakan pola tingkah laku yang disukai seorang pemimpin dalam proses mengarahkan dan mempengaruhi para pekerja. Karakteristik kepemimpinan yang efektif sangat berpengaruh terhadap perilaku

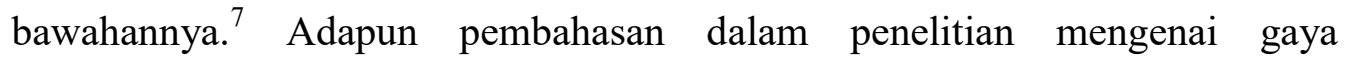
kepemimpinan kepala sekolah sebagai berikut.

a. Cara kepala sekolah dalam memecahkan masalah dan mengambil keputusan

${ }^{6}$ Zainal Arifin, Penelitian Pendidikan: Metode dan Paradigma Baru. (Bandung: PT. Remaja Rosdakarya, 2011) hlm. 143

${ }^{7}$ Nurkholis, Manajemen Berbasis Sekolah, (Jakarta: Grasindo, 2002) hlm. 167 
Qiro'ah| Jurnal Pendidikan Agama Islam

Vol. 11 No. 1 2021| https://ejurnal.iiq.ac.id/index.php/qiroah P-ISSN: 2085-0115 E-ISSN: 2656-3819

DOI: https://doi.org/10.33511/qiroah.v11n1.76-94
Diterima

Direvisi

Disetujui

Diterbitkan
: 14 Mei 2021

: 21 Mei2021

: 14 Juni 2021

: 12 Juni 2021

Menurut Baharudin dan Umiarso fungsi utama menjadi seorang pemimpin salah satunya yaitu, pembuat keputusan yang akan mempengaruhi perkembangan dan kemajuan organisasi serta kesejahteraan para anggotanya. ${ }^{8}$ Berdasarkan pemaparan kepala sekolah cara memecahkan masalah dalam mengambil keputusan, beliau selalu melakukan dengan musyawarah terlebih dahulu dan tidak mengambil keputusan sendiri, musyawarah dilakukan baik bersama guru-guru dengan dimintai pendapat masing-masing, dan juga bersama Tim Penjamin Mutu Internal (TPMI). Di situlah nanti akan ditemukan solusi untuk penyelsaian masalah. Sebagaimana hasil wawancara dengan kepala sekolah SD Islam Plus As-Sa'adatain, yaitu: ${ }^{9}$

“Jadi penyelesaiannya yang pertama kalau berkaitan dengan kelas sepenuhnya diserahkan kepada guru kelas, karna kita setiap hari ada evaluasi dan kemudian setiap bulan juga ada evaluasi. dievaluasi itu jadi kita berbagi persoalan, barangkali dari guru kelas lain bisa membantu menyelesaikan masalah. Yang kedua, saya selalu sampaikan kepada guru kalau hari itu ada masalah, hari itu juga harus diselesaikan. Kalau guru kelas tidak mampu menyelesaikan masalah naiklah ke Tim Penjamin Mutu, dari Tim Penjamin Mutu baru penyelesaian masalahnya. Kita menyelesaikan masalah dibantu sama teman-teman bukan saya sendiri, karna kita punya tim dan memang beberapa kebijakan bukan diambil oleh kepala sekolah saja tapi oleh tim."

Lebih lanjut sebagai penguat pernyataan dari kepala sekolah tersebut, Umi Harofah selaku Tim Penjamin Mutu Internal (TPMI) menyatakan bahwa: ${ }^{10}$

"Kalau kepala sekolah dalam memecahkan masalah beliau akan berkumpul dengan TPMI jadi beliau tidak memecahkan masalah sendiri. Setelah semua TPMI berkumpul lalu dituangkan masalahnya kemudian akan berbagi dan diselesaikan."

Ditegaskan juga oleh pernyataan ka mega selaku staf administrasi sekolah, menyatakan bahwa: ${ }^{11}$

"Alhamdulillah kepala sekolah disini sangat kooperatif, jika ada kendala atau masalah apapun kita sampaikan ke guru kelas dulu, lalu ke kepala sekolah, dan tanggapan kepala sekolah itu sangat respon positif, setiap masalah itu engga ada yang tidak terselesaikan dan pasti akan dicari solusi terbaiknya."

Hal ini juga disetujui oleh Ibu Nurlaila wali murid, beliau mengatakan bahwa: ${ }^{12}$

\footnotetext{
${ }^{8}$ Baharuddin dan Umiarso, Kepemimpinan Pendidikan Islam, (Yogyakarta: Ar-Ruzz Media, 2014) hlm. 38

${ }^{9}$ Wawancara Dengan Kepala Sekolah SD Islam Plus As-Sa’adatain, Umi Yani. Depok, Senin 20 Juli 2020

${ }^{10}$ Wawancara Dengan Tim Penjamin Mutu Internal (TPMI) SD Islam Plus As-Sa'adatain, Umi Harofah. Depok, Senin 20 Juli 2020

11 Wawancara Dengan Staf Administrasi SD Islam Plus As-Sa'adatain, Ka Mega. Depok, Senin 27 Juli 2020
} 
Qiro'ah| Jurnal Pendidikan Agama Islam

Vol. 11 No. 1 2021| https://ejurnal.iiq.ac.id/index.php/qiroah P-ISSN: 2085-0115 E-ISSN: 2656-3819

DOI: https://doi.org/10.33511/qiroah.v11n1.76-94
Diterima

Direvisi

Disetujui

Diterbitkan
: 14 Mei 2021

: 21 Mei2021

: 14 Juni 2021

: 12 Juni 2021

"Kalau menurut saya bagus, kita di sini ada komitte dan Korlas

(Koordinator Kelas), misalnya ada permasalahan di kelas jadi korlas sampaikan ke komite, nanti komite sampaikan ke kepala sekolah, nanti kepala sekolah menanggapi dan setiap masalah pasti dimusyawarahkan."

Kepala sekolah SD Islam Plus As-Sa'datain merupakan orang yang cepat tanggap, sehingga setelah adanya keputusan maka perkembangan masalah yang ada menjadi lebih baik, cepat terselesaikan, dan selalu ada solusi terbaiknya. Beliau selalu mengatakan kepada bawahan bahwa jika ada masalah pada hari itu maka harus diselesaikan pada hari itu juga. Sebagaimana penyataan kepala sekolah, yaitu: ${ }^{13}$

"Saya selalu sampaikan kepada guru kalau hari itu ada masalah hari itu juga harus diselesaikan. Jadi, tidak ada PR untuk masalah, intinya itu dan jangan sampai berkembang. Kalau guru kelas tidak mampu menyelesaikan masalah, naiklah ke Tim Penjamin Mutu, dari Tim Penjamin Mutu baru penyelesaian masalahnya. itulah kenapa adanya briefing pagi, persoalan kemarin itu disampaikan pada briefing pagi. Jadi persoalan yang terjadi kemarin kita bahas pagi itu dan kita selesaikan, pastinya akan ada penyelesaian masalah."

Pernyataan kepala sekolah juga diperkuat oleh Ka Mega selaku staf administrasi, beliau menyatakan bahwa: ${ }^{14}$

"Perkembangan masalahnya setelah ada keputusan menjadi ada solusinya, soalnya sudah hasil kesepakatan dan hasil kesepakatan menjadi solusi, alhamdulillah lancar."

Dapat disimpulkan cara kepala sekolah dalam memecahkan masalah dan mengambil keputusan selalu dilakukan dengan bermusyawah, baik permasalahan tentang guru kelas ataupun permasalahan umum sekolah. $\mathrm{m}$

Musyawarah dilakukan dengan guru-guru dan juga TPMI sekolah. Sebagai seorang pemimpin, untuk memutuskan sesuatu kepala sekolah harus meminta pertimbangan dari guru-guru, walaupun pada akhirnya yang memutuskan adalah kepala sekolah. Setelah adanya keputusan, permasalahan selalu dapat terselesaikan sampai tuntas dan menjadi lebih baik karena adanya solusi yang baik untuk setiap permasalahan.

${ }^{12}$ Wawancara Dengan Wali Murid SD Islam Plus As-Sa'adatain, Ibu Nurlaila. Depok, Selasa 21 Juli 2020 20 Juli 2020

${ }^{13}$ Wawancara Dengan Kepala Sekolah SD Islam Plus As-Sa'adatain, Umi Yani. Depok, Senin

${ }^{14}$ Wawancara Dengan Staf Administrasi SD Islam Plus As-Sa'adatain, Ka Mega. Depok, Senin 27 Juli 2020 
Qiro'ah| Jurnal Pendidikan Agama Islam

Vol. 11 No. 1 2021| https://ejurnal.iiq.ac.id/index.php/qiroah P-ISSN: 2085-0115 E-ISSN: 2656-3819

DOI: https://doi.org/10.33511/qiroah.v11n1.76-94
Diterima

Direvisi

Disetujui

Diterbitkan
: 14 Mei 2021

: 21 Mei2021

: 14 Juni 2021

: 12 Juni 2021

b. Cara kepala sekolah dalam menggerakkan/ memimpin bawahan (guru, staf, siswa)

Adapun fungsi kepala sekolah menurut Dr. H. Muh. Arif, M.Ag. salah satunya yaitu kepala sekolah sebagai Leader (pemimpin). ${ }^{15}$ Kepala sekolah sebagai seorang pemimpin biasanya tidak lepas dari kekuasaan formal yang ketat dan kaku. Lain halnya dengan sikap kepala sekolah di SD Islam Plus As-Sa'adatain, dalam memimpin beliau selalu menunjukkan sikap kekeluargaan, fleksibel, santai, tegas tetapi tidak kaku kepada bawahan. Hal ini dibuktikan oleh pernyataan Umi Harofah selaku Tim Penjamin Mutu Internal (TPMI), yaitu: ${ }^{16}$

"Beliau tegas tapi tidak kaku, khususnya kepada guru-guru dan staf. Kalau ke siswa beliau sangat keibuan. Tidak mentang-mentang kepala sekolah beliau sombong atau sebagainya, itu tidak. Beliau berbaur dengan semuanya."

Pernyataan di atas juga disetujui oleh Abi Solekhan guru Pendidikan Agama Islam (PAI) beliau mengatakan: ${ }^{17}$

"Kalau di As-Sa'adatain enggak, lebih fleksibel dan kekeluargaan."

Kemudian diperkuat oleh pernyataan Ka Mega staf administrasi, beliau mengatakan: ${ }^{18}$

"Kalau menurut saya kepala sekolah luwes, kadang-kadang yang mau kaku dan formal itu dari dinas dan beberapa dari yayasan, tapi untuk kepala sekolah menyampaikan kepada bawahan luwes."

Beberapa pernyataan di atas menunjukkan bahwa kepala sekolah SD Islam Plus As-Sa'adatain dalam memimpin tidak bergantung dalam kekuasaan formal yang ketat dan kaku, melainkan lebih fleksibel, santai, tegas, kekeluargaan dan tetap bertanggung jawab mengayomi guru, staf dan siswa.

Sebelum memerintahkan sesuatu, kepala sekolah selalu memberikan contoh terlebih dahulu. Sebagai seorang pemimpin, kepala sekolah bertugas untuk memberikan contoh-contoh yang baik agar dapat di tiru oleh bawahannya. Contohcontoh yang dilakukan oleh kepala sekolah adalah dari segi kedisiplinan, dan kepribadian. Hal ini dilakukan agar siswa maupun guru yang melihat dapat meniru dan menerapkannya ke dalam kehidupan sehari hari. Dapat disimpulkan bahwa sebelum memerintahkan sesuatu kepada bawahan, kepala sekolah selalu memberi contoh terlebih dahulu.

15 Muh. Arif, Profesi Kependidikan Pedoman dan Acuan Guru Mencintai Profesinya, (Gorontalo: Sultan Amai Press, 2012) hlm. 91

${ }^{16}$ Wawancara Dengan Tim Penjamin Mutu Internal (TPMI) SD Islam Plus As-Sa'adatain, Umi Harofah. Depok, Senin 20 Juli 2020

${ }^{17}$ Wawancara Dengan Guru Pendidikan Agama Islam (PAI) SD Islam Plus As-Sa'adatain, Abi Solekhan. Depok, Selasa 21 Juli 2020

${ }_{18}$ Wawancara Dengan Staf Administrasi SD Islam Plus As-Sa'adatain, Ka Mega. Depok, Senin 27 Juli 2020 
Qiro'ah| Jurnal Pendidikan Agama Islam

Vol. 11 No. 1 2021| https://ejurnal.iiq.ac.id/index.php/qiroah P-ISSN: 2085-0115 E-ISSN: 2656-3819

DOI: https://doi.org/10.33511/qiroah.v11n1.76-94
Diterima

Direvisi

Disetujui

Diterbitkan
: 14 Mei 2021

: 21 Mei2021

: 14 Juni 2021

: 12 Juni 2021

Kepala sekolah memberikan penghargaan kepada bawahan yang berprestasi, dan penghargaan tersebut dapat berupa ucapan selamat, dalam bentuk cindera mata, dan diumumkan di forum ketika peringatan hari guru setiap tahunnya. Jadi kepala sekolah selalu memberikan pengahargaan kepada bawahan guna untuk memotivasi mereka agar terus lebih berprestasi lagi.

Selain pemberian penghargaan kepada yang beprestasi kepala sekolah juga memberikan sanksi kepada bawahan (guru, staf, dan murid) yang bersalah. Sanksi yang diberikan sesuai dengan yang sudah disepakati bersama. Pernyataan ini diperkuat oleh Umi Harofah Tim Penjamin Mutu Internal (TPMI), yaitu: ${ }^{19}$

"Jika ada guru yang melanggar beliau juga memberikan sanksi sesuai peraturan yang berlaku. Pertama dipanggil secara pribadi lalu dinasehati, jika melanggar dipanggil dengan Tim Penjamin Mutu, jika masih melanggar untuk ketiga kalinya akan diberikan Surat Peringatan (SP) 1."

Lebih lanjut Abi Solekhan guru Pendidikan Agama Islam mengatakan bahwa: ${ }^{20}$

"Iya ada, jika ada yang melanggar akan diberikan sanksi dan jika ada ada kekurangan perlu diperbaiki.'Kepala sekolah memberikan sanksi kepada tenaga kependidikan sesuai dengan peraturan yang sudah ditetapkan, hal ini dinyatakan oleh Ka Mega staf administrasi: ${ }^{21}$

Berdasarkan beberapa pendapat di atas bahwa kepala sekolah selalu memberikan sanksi jika ada bawahan yang melanggar peraturan yang sudah ditetapkan. Sanksi yang diberikan oleh kepala sekolah terhadap bawahan ada beberapa tahapan mulai dari berupa nasehat, teguran, bimbingan, itu semua dilakukan guna untuk menjadi lebih baik. Sebagai seorang pemimpin partisipasi kepala sekolah juga sangat penting terutama kegiatan di sekolah maupun kegiatan di luar sekolah. Hal ini diperkuat oleh penyataan Ka Mega staf administrasi, yaitu: ${ }^{22}$

"Selama di sini beliau selalu berpartisipasi aktif dalam kegiatan yang ada, terlibat dalam kepanitiaan maupun menjadi peserta, baik kegiatan di sekolah maupun di luar sekolah." Ungkapan tersebut juga disetujui oleh Abi Solekhan guru Pendidikan Agma Islam (PAI) beliau mengatakan bahwa: ${ }^{23}$ "Selalu berpartisipasi dan bahkan menghimbau, juga berperan aktif."

\footnotetext{
${ }^{19}$ Wawancara Dengan Tim Penjamin Mutu Internal (TPMI) SD Islam Plus As-Sa'adatain, Umi Harofah. Depok, Senin 20 Juli 2020

${ }^{20}$ Wawancara Dengan Guru Pendidikan Agama Islam (PAI) SD Islam Plus As-Sa'adatain, Abi Solekhan. Depok, Selasa 21 Juli 2020

${ }^{21}$ Wawancara Dengan Staf Administrasi SD Islam Plus As-Sa'adatain, Ka Mega. Depok, Senin 27 Juli 2020

${ }^{22}$ Wawancara Dengan Staf Administrasi SD Islam Plus As-Sa'adatain, Ka Mega. Depok, Senin 27 Juli 2020

${ }^{23}$ Wawancara Dengan Guru Pendidikan Agama Islam (PAI) SD Islam Plus As-Sa'adatain, Abi Solekhan. Depok, Selasa 21 Juli 2020
} 
Qiro'ah| Jurnal Pendidikan Agama Islam

Vol. 11 No. 1 2021| https://ejurnal.iiq.ac.id/index.php/qiroah P-ISSN: 2085-0115 E-ISSN: 2656-3819

DOI: https://doi.org/10.33511/qiroah.v11n1.76-94
Diterima

Direvisi

Disetujui

Diterbitkan
: 14 Mei 2021

: 21 Mei2021

: 14 Juni 2021

: 12 Juni 2021

Kepala sekolah juga ikut berpartisispasi dalam kegiatan bersama wali murid, hal ini disampaikan oleh Ibu Nurlaila selaku wali murid, yaitu: ${ }^{24}$

"Kegiatan khusus kita ada pembelajaran Tahsin satu minggu sekali, kepala sekolah juga mengikuti kegiatan ini”

Beberapa pernyataan di atas dapat membuktikan bahwa kepala sekolah di SD Islam Plus As-Sa'adatain merupakan kepala sekolah yang sangat aktif dan selalu berpartisipasi dan berperan aktif dalam segala kegiatan yang ada di sekolah maupun di luar sekolah.

Setelah pemaparan di atas dapat disimpulkan bahwa dalam menggerakkan/ memimpin bawahan (guru, staf dan siswa) sudah baik menjalankan perannya sebagai leader (pemimpin), dibuktikan dengan kepala sekolah tidak bergantung pada kekuasaan yang formal ketat dan kaku, bersikap santai, tegas, fleksibel, disiplin tidak terlalu formal tetapi tetap bertanggung jawab serta dapat mengayomi serta selalu memberikan contoh terlebih dahulu sebelum memerintah. Selain itu, kepala sekolah selalu berpartisipasi aktif dalam kegiatan yang ada disekolah maupun di luar sekolah dan memberikan penghargaan khusus selalu dilakukan oleh kepala sekolah terhadap bawahan yang berprestasi, dan juga memberikan sanksi terhadap bawahan yang bersalah.

c. Kepribadian yang dimiliki oleh kepala sekolah SD Islam Plus AsSa'adatain

Kompetensi kepala sekolah/madrasah seperti yang terdapat dalam Peraturan Menteri Pendidikan Nasional Nomor 13 Tahun 2007 tentang Standar Kepala Sekolah/Madrasah. Dalam peraturan tersebut terdapat lima dimensi kompetensi yaitu: kepribadian, manajerial, kewirausahaan, supervisi, dan sosial. Setiap dimensi kompetensi memiliki kompetensi dasar yang harus dimiliki seorang kepala sekolah/madrasah. ${ }^{25}$

Salah satu dari 5 kompetensi itu ada Kompetensi Kepribadian, adapun maksud dari kompetensi kepribadian yaitu:

a. Berakhlak mulia, mengembangkan budaya dan tradisi akhlak mulia, dan menjadi teladan akhlak mulia bagi komunitas di sekolah/madrasah.

b. Memiliki integritas kepribadian sebagai pemimpin.

c. Memiliki keinginan yang kuat dalam pengembangan diri sebagai kepala sekolah/madrasah

d. Bersikap terbuka dalam melaksanakan tugas pokok dan fungsi.

e. Mengendalikan diri dalam menghadapi masalah dalam pekerjaan sebagai kepala sekolah/ madrasah.

f. Memiliki bakat dan minat jabatan sebagai pemimpin pendidikan. 21 Juli 2020

${ }^{24}$ Wawancara Dengan Wali Murid SD Islam Plus As-Sa'adatain, Ibu Nurlaila. Depok, Selasa

25 http://lppks.kemdikbud.go.id/id/kabar/kompetensi-dan-kepemimpinan-kepala-sekolah/ search pada tanggal 25/07/2020 jam 21.01 
Qiro'ah| Jurnal Pendidikan Agama Islam

Vol. 11 No. 1 2021| https://ejurnal.iiq.ac.id/index.php/qiroah P-ISSN: 2085-0115 E-ISSN: 2656-3819

DOI: https://doi.org/10.33511/qiroah.v11n1.76-94
Diterima $\quad: 14$ Mei 2021

Direvisi : 21 Mei2021

Disetujui : : 14 Juni 2021

Diterbitkan : 12 Juni 2021

Sikap kepala sekolah terhadap bawahan (guru, staf, siswa) selalu mengutamakan rasa kekeluargaan dan persaudaraan, beliau sangat ramah, baik, santun, berwibawa, mengayomi dan tidak membeda-bedakan siapapun. Sebagaimana pernyataan yang disampaikan oleh kepala sekolah, yaitu: ${ }^{26}$

"Kita punya prinsip persaudaraan, tidak ada senior dan junior, apapun itu kita bicarakan dengan baik. Contohnya saya tidak malu untuk nongkrong di pos, kita makan bareng di pos dengan penjaga. Tidak merasa bahwa kita pimpinan dan tidak bergaul dengan bawahan, tidak merasa begitu. Kita makan bareng ngobrol bareng, dengan begitu kita tau keluh kesah dia apa dan merasa lebih terbuka. Dari awal saya selalu bilang yok sama-sama, di sini tempatnya kita berjuang."

Hal tersebut sesuai dengan pernyataan Ibu Nida selaku wali murid bahwa beliau tidak membedakan siapapun dan apapun jabatannya, beliau mengatakan bahwa: ${ }^{27}$

"Kepala sekolah disini kebetulan orangnya friendly banget, dengan wali murid yang lain ada tegur sapanya salamnya, jadi kita wali murid ngerasa nyaman aja walaupun beliau itu kepala sekolah, tidak otoriter dan nakutin tapi ini malah kaya temen."

Hal ini juga diperkuat oleh pernyataan Umi harofah Tim Penjamin Mutu Internal (TPMI), yaitu: ${ }^{28}$

"Beliau orangnya fleksibel ya, jadi ketika dengan siswa seperti apa, ketika dengan guru seperti apa. Ketika di luar zona sekolah beliau layaknya seorang teman dan bisa menempatkan posisinya."

Beberapa pernyataan di atas dapat disimpulkan bahwa sikap kepala sekolah terhadapa bawahan (guru, staf, siswa) yaitu ramah, sopan, santun, berwibawa, tidak membedabedakan siapapun, selalu mengayomi, dan juga selalu mengutamakan rasa kekeluargaan.

Jadi dapat disimpulkan bahwa kedisiplinan yang dimiliki kepala sekolah SD Islam Plus As-Sa'adatain sangatlah tinggi. Hal ini terlihat dari sikap yang ditunjukkan setiap harinya. Setiap hari kepala sekolah selalu datang lebih awal dari guru-guru dan juga selalu disiplin terhadap waktu yang sudah ditentukan.

Kepala sekolah SD Islam Plus As-Sa'datain tidak hanya memiliki kedisiplinan yang tinggi, tetapi juga memiliki rasa percaya diri yang tinggi. Dalam memimpin, kepala sekolah memiliki rasa sangat percaya diri, terlihat pada saat mengambil keputusan untuk mengijinkan penulis melaksanakan penelitian di SD Islam Plus AsSa'adatain. Selain itu, kepala sekolah terlihat sangat percaya diri dan tegas dalam

\footnotetext{
${ }^{26}$ Wawancara Dengan Kepala Sekolah SD Islam Plus As-Sa'adatain, Umi Yani. Depok, Senin 20 Juli 2020

${ }^{27}$ Wawancara Dengan Wali Murid SD Islam Plus As-Sa'adatain, Ibu Nida. Depok, Selasa 21 Juli 2020

${ }^{28}$ Wawancara Dengan Tim Penjamin Mutu Internal (TPMI) SD Islam Plus As-Sa'adatain, Umi Harofah. Depok, Senin 20 Juli 2020
} 
Qiro'ah| Jurnal Pendidikan Agama Islam

Vol. 11 No. 1 2021| https://ejurnal.iiq.ac.id/index.php/qiroah P-ISSN: 2085-0115 E-ISSN: 2656-3819

DOI: https://doi.org/10.33511/qiroah.v11n1.76-94
Diterima

Direvisi

Disetujui

Diterbitkan
: 14 Mei 2021

: 21 Mei2021

: 14 Juni 2021

: 12 Juni 2021

mengambil keputusan, beliau percaya selama itu baik pasti hasilnya akan baik. Tidak hanya itu, kepala sekolah dan guru, siswa-siswi juga mengatakan hal yang sama bahwa kepala sekolah memiliki rasa percaya diri yang sangat besar. sehingga hal tersebut dapat menjadi contoh teladan yang perlu ditiru oleh guru maupun siswa.

Tidak hanya memiliki rasa percaya diri, dalam kepemimpinannya kepala sekolah juga mengutamakan rasa persatuan dan kesatuan. Sebagaimana prinsip As-Sa'adatain selalu mengutamakan rasa persaudaraan. Sebagaimana yang dikatakan kepala sekolah dalam wawancara, bahwa: ${ }^{29}$

"Pasti, contohnya banyak kegiatan-kegiatan yang sifatnya kebersamaan. Setiap hari kita ada makan bareng kegiatan bareng, pada prinsipnya lembaga AsSa'adatain yang mengedapankan rasa persaudaraan. Kalau ada masalah antar personal harus cepat diselesaikan."

Beberapa pernyataan di atas membuktikan bahwa, tidak hanya rasa percaya diri, kepala sekolah juga selalu mengutamakan rasa persatuan dan kesatuan, kekompakan dan menciptakan kerjasama yang baik dengan guru, staf, maupun seluruh siswa yang ada di SD Islam Plus As-Sa'adatain. Selalu ada kebersamaan setiap harinya antar warga sekolah. Tidak hanya itu, kepala sekolah juga selalu mengadakan kegiatan di luar sekolah seperti Outing Class, Family Gathering dan lainnya, demi terciptanya rasa persatuan dan kesatuan.

Jadi dapat disimpulkan bahwa kepribadian yang dimiliki kepala sekolah mulai dari sikap kepala sekolah terhadap bawahan, kedisiplinan, rasa percaya diri, rasa persatuan dan kesatuan, dan sikap kepala sekolah dalam memimpin sekolah terbilang sudah baik dan patut untuk diteladani.

Cara kepala sekolah SD Islam Plus AS-Sa'adatain dalam berkomunikasi dengan (guru, staf, siswa). Adapun sikap kepala sekolah dalam menjaga komunikasi yang baik dengan guru, staf, siswa dilakukan kapan saja, dan kepala sekolah selalu berperilaku baik terhadap siapa saja tanpa mengenal perbedaan. Seperti pada waktu istirahat kepala sekolah bertegur sapa dan berbaur dengan siswa guna untuk menumbuhkan komunikasi dan hubungan yang baik kepada siswa. Sebagaimana pernyataan kepala sekolah ketika wawancara, bahwa: ${ }^{30}$

Berdasarkan hasil wawancara dan didukung oleh hasil observasi yang dilakukan, kepala sekolah selalu bersikap santai, ramah, sopan, santun, hangat, harmonis, tegas, dan berwibawa. Kepala sekolah adalah orang yang aktif dan memiliki tingkat sosialisasi yang tinggi, sebagaimana dalam Peraturan Menteri Pendidikan Nasional Nomor 13 Tahun 2007 tentang Standar Kepala Sekolah/Madrasah, dalam peraturan tersebut terdapat lima dimensi kompetensi salah satunya yaitu kompetensi sosial. Hal ini dibuktikan pada saat kepala sekolah sedang berbincang-bincang dengan

${ }^{29}$ Wawancara Dengan Kepala Sekolah SD Islam Plus As-Sa'adatain, Umi Yani. Depok, Senin 20 Juli 2020

${ }^{30}$ Wawancara Dengan Kepala Sekolah SD Islam Plus As-Sa'adatain, Umi Yani. Depok, Senin 20 Juli 2020 
Qiro'ah| Jurnal Pendidikan Agama Islam

Vol. 11 No. 1 2021| https://ejurnal.iiq.ac.id/index.php/qiroah P-ISSN: 2085-0115 E-ISSN: 2656-3819

DOI: https://doi.org/10.33511/qiroah.v11n1.76-94
Diterima

Direvisi

Disetujui

Diterbitkan
: 14 Mei 2021

: 21 Mei2021

: 14 Juni 2021

: 12 Juni 2021

guru, staf, siswa, dan juga wali murid. Dapat disimpulkan bahwa Sikap kepala sekolah pada saat berkomunikasi dengan bawahan baik, santai, ramah, sopan, santun, hangat, harmonis, tegas, sangat komunikatif, dan berwibawa.

Selain terbuka dalam komunikasi, kepala sekolah juga terbuka dalam menerima kritik dan saran dari bawahan. Hal ini diungkapkan kepala sekolah: ${ }^{31}$

"Kalau saya lebih terbuka dan sudah memahami beberapa karakter, ketika ada kritikan dan saran kita sudah tau karakter si A seperti ini dan siap menerima apapun itu. Karena memang harus seperti itu, bukan seorang pemimpin ketika diberikan masukan kemudian menolak, tapi berusaha untuk menerima. Karena tujuan sebenarnya juga untuk peningkatan kualitas lembaga." Ungkapan tersebut didukung oleh penyataan guru dan staf. Sikap kepala sekolah dalam menerima pendapat, kritik, dan saran selalu diterima dengan ikhlas dan tidak monoton. Kepala sekolah juga orang yang sangat mendengarkan pendapat dari bawahan siapapun itu dan apapun jabatannya.

Beberapa pernyataan di atas dapat disimpulkan bahwa sikap kepala sekolah dalam menerima kritik dan saran selalu bersikap baik, menerima dengan lapang dada dan menerima apapun masukan dari bawahan. Selain itu, kepala sekolah setelah menerima masukan akan langsung ditindak lanjuti karena tujuannya untuk meningkatkan kualitas lembaga.

\section{Kepala Sekolah SD Islam Plus As-Sa'adatain dalam Meningkatkan Mutu} Pendidikan Islam.

SD Islam Plus As-Sa'adatain didirikan pada tahun 2008 yang bergerak di dunia pendidikan berciri khas religius mendidik siswa-siswi menjadi pribadi yang cerdas, keratif dan berakhlakul karimah sesuai dengan visi dan misi. SD Islam Plus As-Sa'adatain selalu menerapkan visi misi yang ada, maka dari itu sekolah sangat unggul dibidang pendidikan Islam, baik dalam pembelajaran, pembiasaanya adab Islami setiap harinya, banyak sekali prestasi sekolah dalam bidang ke-Islam-an sehingga mencapai prestasi sekolah unggulan berakreditasi A.

Kepala Sekolah mempunyai peran yang penting dalam meningkatkan mutu pendidikan Islam di sekolah. Butuh bermacam cara untuk mengembangkan kualitas sekolah menjadi lebih baik. Untuk itu diperlukan sebuah kepemimpinan yang baik dan program pendukung pendidikan Islam. Inilah beberapa upaya kepala sekolah dalam meningkatkan mutu pendidikan Islam di SD Islam Plus As-Sa'adatain Gandul Cinere:

a. Membentuk Tim Penjamin Mutu Internal (TPMI) 20 Juli 2020

${ }^{31}$ Wawancara Dengan Kepala Sekolah SD Islam Plus As-Sa'adatain, Umi Yani. Depok, Senin 
Qiro'ah| Jurnal Pendidikan Agama Islam

Vol. 11 No. 1 2021| https://ejurnal.iiq.ac.id/index.php/qiroah P-ISSN: 2085-0115 E-ISSN: 2656-3819

DOI: https://doi.org/10.33511/qiroah.v11n1.76-94
Diterima

Direvisi

Disetujui

Diterbitkan
: 14 Mei 2021

: 21 Mei2021

: 14 Juni 2021

: 12 Juni 2021

Salah satu upaya kepala sekolah SD Islam Plus As-Sa'adatain dalam meningkatkan mutu pendidikan Islam yaitu dibentuknya Tim Penjamin Mutu Internal (TPMI). Tim Penjamin Mutu Internal (TPMI) berjumlah 6 orang yang terdiri dari kepala sekolah, wakil kepala sekolah bidang kurikulum, wakil kepala sekolah bidang kesiswaan, dan 2 orang guru yang ditunjuk oleh kepala sekolah. Awal terbentuknya Tim Penjamin Mutu Internal (TPMI) di SD Islam As-Sa'adatain pada saat Umi Yani menjabat jadi kepala sekolah, hal ini dikatakan oleh Umi Harofah selaku Tim Penjamin Mutu Internal (TPMI), beliau mengatakan bahwa: ${ }^{32}$

“Awal dibentuk ketika Umi Yani menjabat menjadi kepala sekolah barulah dibentuknya Tim Penjamin Mutu Internal (TPMI). Tugas Tim Penjamin Mutu Internal (TPMI) salah satunya bertanggung jawab atas kurikulum yang berkaitan dengan Islamic Suplementary karena brand dari SD Islam Plus As-Sa'adatain yaitu Islamic Suplementary, membantu kepala sekolah dalam mengatasi berbagai macam permasalahan di sekolah, dan juga membantu kepala sekolah dalam melaksanakan supervisi. Sebagaimana yang dikatakan kepala sekolah dalam wawancara, bahwa: ${ }^{33}$

Pernyataan kepala sekolah juga diperkuat oleh pernyataan Umi Harofah Tim Penjamin Mutu Internal (TPMI), beliau mengatakan bahwa: ${ }^{34}$

"Salah satunya penguatan di Islamic Suplementary. Kita dari tim akan berembuk dulu sebelum dinfokan kepada guru-guru, seperti membicarakan dimasa pandemi ini bagaimana supaya siswa tetap bisa Ta'lim Tahfidz, makanya kita mengadakan home visit. Jadi siswa tetap mendapatkan hak dari Islamic Suplementary."

Tim Penjamin Mutu Internal (TPMI) sangat berperan dalam meningkatkan mutu pendidikan Islam di SD Islam Plus As-Sa'adatain, karena Tim Penjamin Mutu Internal (TPMI) mempunyai tugas salah satunya penguatan kurikulum Islamic Suplementary yang mana kurikulum tersebut menjadi brand dari SD Islam Plus As-Sa'adatain.

b. Kurikulum Islamic Suplementary

SD Islam Plus As-Sa'adatain berbeda dengan sekolah pada umunya yang hanya menggunakan kurikulum nasional yang ditentukan oleh pemerintah, tetapi sekolah ini juga mempunyai kurikulum tersendiri yaitu Islamic Suplementary.

${ }^{32}$ Wawancara Dengan Tim Penjamin Mutu Internal (TPMI) SD Islam Plus As-Sa'adatain, Umi Harofah. Depok, Senin 20 Juli 2020 20 Juli 2020

${ }^{33}$ Wawancara Dengan Kepala Sekolah SD Islam Plus As-Sa'adatain, Umi Yani. Depok, Senin

${ }^{34}$ Wawancara Dengan Tim Penjamin Mutu Internal (TPMI) SD Islam Plus As-Sa'adatain, Umi Harofah. Depok, Senin 20 Juli 2020 
Qiro'ah| Jurnal Pendidikan Agama Islam

Vol. 11 No. 1 2021| https://ejurnal.iiq.ac.id/index.php/qiroah P-ISSN: 2085-0115 E-ISSN: 2656-3819

DOI: https://doi.org/10.33511/qiroah.v11n1.76-94
Diterima

Direvisi

Disetujui

Diterbitkan
: 14 Mei 2021

: 21 Mei2021

: 14 Juni 2021

: 12 Juni 2021

Islamic Suplementary adalah kurikulum khas SD Islam Plus AsSa'adatain yang menjadikan sekolah ini memiliki nilai lebih dibandingkan dengan lembaga pendidikan tingkat sekolah dasar lainnya. Kurikulum ini diadopsi dari nilai-nilai pesantren, didesain untuk menyiapkan peserta didik menjadi insan yang berakhlakul karimah sesuai dengan tujuan pendidikan Islam. Islamic Suplementary dilaksanakan dengan proses pembiasaan, untuk menciptakan lingkungan pendidikan dan pembelajaran yang menyenangkan dan Islami. Sebagaimana pernyataan Umi Yani selaku kepala sekolah, bahwa: ${ }^{35}$

“Islamic Suplementary di antaranya ada tahfizh, Ta'limul Qur 'an, dan pembiasaan-pembiasaan Islam lainnya. Mungkin di lembaga swasta lain biasanya pendidikan agama itu lebih ke teori, tapi kalau kita pendidikan agama dikemas dalam Islamic Suplementary. Jadi, anak tetap kita berikan materi, tetapi bobotnya lebih kepada pembiasaan"

Kurikulum Islamic Suplementary disusun sangat rapi dan tertulis dalam satu buah buku panduan. Kurikulum ini terdiri dari: Ta'limul Qur'an, Tahfizhul Qur'an, praktek ibadah, do'a-do'a harian, menulis Arab dan imla', sholat Dhuha dan Zhuhur berjamaah, biah lughowiyah (pembiasaan berbahasa Arab dan Inggris sebagai bahasa intruksi di kelas), dan (Islamic culture pembiasaan adab Islami).

1) Ta’limul Qur'an

Pembelajaran menggunakan dengan metode Iqra' dilaksanakan secara Muwajjah, yaitu setiap siswa membaca satu persatu di hadapan guru, sedangkan guru menyimak bacaan siswa. Jika bacaan siswa dianggap benar sesuai kaidah bacanya maka peserta didik dapat melanjutkan ke bacaan selanjutnya, jika belum benar maka siswa mengulangi bacaannya pada hari berikutnya.

Ta'limul Qur'an dilaksanakan setiap pagi hari sebelum Kegiatan Belajar Mengajar berlangsung dan siswa dibagi menjadi 2 kelompok. Siswa membaca sambil disimak oleh guru dengan memperhatikan makhraj, mad dan kelancarannya (maksimal 4 baris untuk Iqro' dan 3 ayat untuk al-Qur'an) disesuaikan dengan kemampuan siswa. Setiap hari guru berkewajiban untuk mencatat perkembangan bacaan siswa pada prestasi ta'limul Qur'an. Pelaksanaan ta'limul Qur'an mempunyai target untuk siswa di setiap semesternya dan di setiap jenjang kelasnya.

2) Tahfizhul Qur'an

Pembelajaran Tahfizhul Qur'an dilaksanakan dengan metode demonstrasi dan pengulangan terus menerus, guru mentalaqqi yaitu

${ }^{35}$ Wawancara Dengan Kepala Sekolah SD Islam Plus As-Sa'adatain, Umi Yani. Depok, Senin 
Qiro'ah| Jurnal Pendidikan Agama Islam

Vol. 11 No. 1 2021| https://ejurnal.iiq.ac.id/index.php/qiroah P-ISSN: 2085-0115 E-ISSN: 2656-3819

DOI: https://doi.org/10.33511/qiroah.v11n1.76-94
: 14 Mei 2021

: 21 Mei2021

: 14 Juni 2021

: 12 Juni 2021

membimbing siswa untuk membaca ayat/surah sesuai kaidah tajwid yang benar, kemudian siswa mengikutinya, dibaca secara jama'i (bersama-sama) setiap hari (tahfizh bin nadzar).

Kegiatan ini dilaksanakan setelah kegiatan KBM setelah sholat Dzuhur untuk kelas 1-3 dan sebelum sholat Dzuhur untuk kelas 4-6, lalu siswa dibagi menjadi 2 kelompok. Siswa membaca ayat/surah yang sudah dibaca kepada guru, diperbolehkan bagi siswa yang sudah lancar hafalannya untuk menyimak bacaan temannya, sebelum mentalaqqi guru memprogram pengulangan hafalan untuk surah-surah yang sudah dihafal siswa pada kelas sebelumnya, dan siswa dinyatakan lancar apabila sudah tepat makhroj, mad, dan kemampuan hafalannya.

Kejelian dan ketelitian guru sangat berpengaruh terhadap hafalan siswa. Adapun target hafalan siswa untuk siswa kelas 1 sampai kelas 4 sudah selesai hafal juz 30, dan untuk kelas 5 dan 6 mengafal surat-surat pilihan seperti surat Yasin, Al-Waqi'ah, Ar-Rahman dan AlFath. Hasil hafalan siswa dilaporkan dalam buku prestasi tahfizhul Qur`an..

Siswa yang tidak dapat menyelsaikan target hafalan persemester maka tidak dapat mengambil rapot semester sebelum menyelesaikan target hafalannya. Hal ini dibenarkan oleh Ibu Nida, wali murid dalam wawancara, bahwa: ${ }^{36}$

"Alhamdulillah bagus, banyak mencetuskan penghafal Al-

Qur`an walaupun hanya juz 30. Jadi, kalau kelas 6 lulus dengan belum selesai juz 30 belum dikasih ijazah. Juga kalau dari kelas 1 ke kelas 2 belum memenuhi target jadi belum bisa naik."

Adapun penghargaan atau apresiasi dari sekolah bagi siswa yang sudah menyelesaikan target hafalan juz 30 akan mengikuti wisudah tahfizh yang diadakan setiap tahunnya oleh sekolah.

3) Praktek Ibadah

Adapun metode pembelajaran praktek ibadah dilaksanakan secara berulang-ulang, hal ini dimaksudkan agar peserta didik benarbenar mampu melaksanakan praktek ibadah dengan baik dan benar. Disampaikan 1 jam pelajaran setiap satu minggu sekali bergantian dengan materi doa-doa harian (dicantumkan dalam kalender pembelajaran mingguan) guru memperhatikan gerakan dan bacaan siswa. Pelaksanaan praktek ibadah mempunyai target untuk siswa di setiap semesternya dan di setiap jenjang kelasnya.

${ }^{36}$ Wawancara Dengan Wali Murid SD Islam Plus As-Sa'adatain, Ibu Nida. Depok, Selasa 21 
Qiro'ah| Jurnal Pendidikan Agama Islam

Vol. 11 No. 1 2021| https://ejurnal.iiq.ac.id/index.php/qiroah P-ISSN: 2085-0115 E-ISSN: 2656-3819

DOI: https://doi.org/10.33511/qiroah.v11n1.76-94
Diterima

Direvisi

: 14 Mei 2021

Disetujui

Diterbitkan
: 21 Mei2021

: 14 Juni 2021

: 12 Juni 2021

Hasil dari pelaksanaan prakter ibadah juga dirasakan oleh Ibu Nida wali murid, beliau mengatakan bahwa: ${ }^{37}$

"Alhamdulillah bagus banget, karena saya kurang basic agama.

Dulu anak saya sholatnya ngasal sekarang cara duduknya benar, terus cara bacaannya, makhorijul hurufnya, bangga gitu baru kelas satu naik kelas dua tapi dia udah bisa."

Pernyataan wali murid di atas membuktikan bahwa penerapan praktek ibadah di sekolah sudah bagus dan siswa juga menerapkannya sendiri di rumah.

4) Do'a-do'a Harian

Pelaksanakan pembelajaran do'a-do'a harian secara berulangulang, hal ini dimaksudkan agar peserta didik benar-benar mampu membaca doa-doa harian dengan baik dan benar, disampaikan 1 jam pelajaran setiap satu minggu sekali bergantian dengan materi doa-doa harian (dicantumkan dalam kalender pembelajaran mingguan), guru juga memperhatikan bacaan siswa (makharijul huruf dan mad). Pelaksanaan do'a-do'a harian mempunyai target untuk siswa di setiap semesternya dan di setiap jenjang kelasnya.

5) Menulis Arab dan Imla

Metodologi pembelajaran menulis Arab dengan cara guru menulis huruf/kata/kalimat di papan tulis, dan peserta didik menulisnya di buku latihan menulis Arab. Pelaksanaannya bersamaan dengan ta'limul Qur'an yaitu ketika siswa menunggu antrian untuk membaca Iqro'/Al-Qur'an.

Pemberian materi imla' dilaksanakan ketika pembelajaran bahasa Arab, guru mendikte kosa kata yang terdapat pada materi bahasa Arab, materi ini diberikan mulai kelas III semester II s.d Kelas VI.

6) Sholat Dhuha dan Zhuhur Berjamaah

Proses pembiasaan beribadah dengan baik dan benar dilaksanakan dengan cara pembiasaan, yang bertujuan agar peserta didik dapat terbiasa melaksanakan ibadah sholat fardhu tepat pada waktunya, yang di awali dari pembiasaan di sekolah.

Dikarenakan terbatasnya waktu, maka sekolah hanya membimbing peserta didik untuk melaksanakan sholat Duha dan Zhuhur secara berjamaah, adalah pelaksanaannya diajarkan juga dzikir dan do'a setelah sholat, diharapkan peserta didik dapat melaksanakan sholat dengan baik dan benar sesuai dengan ajaran syariat dan mampu berdzikir dan berdoa secara mandiri. 
Qiro'ah| Jurnal Pendidikan Agama Islam

Vol. 11 No. 1 2021| https://ejurnal.iiq.ac.id/index.php/qiroah P-ISSN: 2085-0115 E-ISSN: 2656-3819

DOI: https://doi.org/10.33511/qiroah.v11n1.76-94
Diterima

Direvisi

Disetujui

Diterbitkan
: 14 Mei 2021

: 21 Mei2021

: 14 Juni 2021

: 12 Juni 2021

Sholat Duha dilaksanakan setelah pemberian materi conversation/ muhadatsah, adapun urutan pelaksanaannya dimulai setelah berwudhu, membaca Asmaul husna, dilanjut membaca sholawat, lalu sholat Duha 2 rakaat dan ditutup dengan doa Sholat Duha.

Sholat zhuhur dilaksanakan secara bergantian, kelas 1 sampai 3 pada jam 12. 30 WIB, sedangkan kelas 4 sampai 6 pada jam 12.00 WIB. Adapun urutan pelaksanaannya adalah: Setelah berwudhu melaksanakan sholat sunnah 2 rakaat, dilanjutkan Membaca Sholawat, lalu pelaksanaan sholat Zhuhur, dan terakhir berdzikir dilanjutkan dengan doa.

7) Biah lughowiyah (pembiasaan berbahasa Arab dan Inggris sebagai bahasa intruksi di kelas)

Proses pembiasaan berbahasa Arab \& Inggris di SD Islam Plus As-Sa'adatain masih dalam tahap awal, yakni hanya sebagai bahasa instruksi dari guru, dan bahasa komunikasi dasar disesuaikan dengan beban materi yang diajarkan pada setiap kelas.

Penggunaan dua bahasa Arab dikarenakan bahasa Arab adalah bahasa al-Qur'an sedangkan bahasa Inggris adalah bahasa komunikasi internasional. Pelaksanaanya dengan dua cara; pertama diberikan di awal masuk, ketika para siswa berbaris di selasar/depan kelas, kedua penggunaannya di dalam kelas, baik dalam bahasa instruksi dari guru maupun ketika peserta didik meminta izin kepada guru.

8) Islamic Culture (Pembiasaan Adab Islami)

Adapun yang dimaksud dengan Islamic culture adalah pembiasaan akhlakul karimah di dalam pergaulan keseharian di sekolah dan di rumah, di antara Islamic culture yang diterapkan di SD Islam Plus As-Sa'adatain adalah:

a) Mengucapkan salam ketika bertemu guru, ketika masuk kantor, ketika masuk kelas.

b) Menghormati yang lebih tua dan menyayangi yang lebih muda.

c) Berprilaku sopan kepada teman dan guru.

d) Membuang sampah pada tempatnya.

e) Melaksanakan sholat fardu pada waktunya baik di sekolah maupun di rumah.

f) Membiasakan mengaji/atau membaca al-Qur'an.

g) Makan dan minum dengan tertib (tidak sambil bardiri apalagi berjalan.

h) Bertutur kata yang sopan (tidak mengucapkan kata-kata umpatan, atau kata-kata kotor).

i) Membiasakan prilaku tanggung jawab, disiplin, mandiri, dan jujur. 
Qiro'ah| Jurnal Pendidikan Agama Islam

Vol. 11 No. 1 2021| https://ejurnal.iiq.ac.id/index.php/qiroah P-ISSN: 2085-0115 E-ISSN: 2656-3819

DOI: https://doi.org/10.33511/qiroah.v11n1.76-94
Diterima

Direvisi

Disetujui

Diterbitkan
: 14 Mei 2021

: 21 Mei2021

: 14 Juni 2021

: 12 Juni 2021

Siswa yang tidak menerapkan pembiasaan Islami ini atau ada siswa yang berperilaku tidak sesuai dengan yang sudah ditetapkan, maka akan ada hukuman bagi siswa, hukuman yang diberikan tidak dalam bentuk fisik tetapi dalam bentuk pembiasaan Islami. Sebagaimana yang disampaikan Umi Yani kepala sekolah, bahwa: ${ }^{38}$

"Untuk akhlak, kita tidak memperkenankan siswa makan dan minum sambil berdiri, jika siswa makan dan minum di lapangan pasti langsung jongkok, jadi pendidikan agama lebih kepada pembiasaan kalau di lembaga kita. Contoh lainnya juga di awal masuk kelas ada kesepakatan kelas diantaranya jika anak masuk tidak memberi salam, berbicara "gua" atau "elu", mereka mempunyai hukuman yang disepakati bersama anak-anak, karena akan lebih mengena kalau hukuman disepakati bersama, seperti hukuman yang utama membaca istighfar, baca Al-Qur’an. Jadi hukumannya dalam bentuk pembiasaan yang baik, tidak ada bentuk fisik seperti membersihkan kamar mandi."

Dapat disimpulkan bahwa penerapan Islamic Culture di sekolah sudah baik, dan siswa tidak hanya menerapkan ketika di sekolah tetapi juga dipraktekkan ketika di rumah.

\section{c. Peningkatan kualitas SDM (Sumber Daya Manusia)}

Pembinaan SDM menjadi sangat penting untuk proses pendidikan, oleh karena itu kepala sekolah melakukan pembinaan ketika tenaga pendidikan dan kependidikan sudah diterima untuk mengikuti segala pembinaan dalam peningkatan kualitas. Ada peningkatan skill dan pelatihan serta worksop, pembinaan yang dilakukan kepala sekolah terhadap bawahan menggunakan dua cara, yaitu secara global dan individual. Pembinaan secara global adalah pembinaan yang dilakukan di dalam RAKER (Rapat Kerja) sebelum awal tahun ajaran baru dan ditujukan untuk semua guru, maupun staf. Sedangkan pembinaan yang dilakukan secara individual yaitu yang bersangkutan dipanggil perorangan. Sebagaimana Umi Yani kepala sekolah menyatakan dalam wawancara, bahwa: ${ }^{39}$

"Ketika RAKER (Rapat Kerja) itu kita ada 1 hari untuk peningkatan SDM, jadi kita panggil guru dari luar. Kedua untuk peningkatan SDM ada pelatihan-pelatihan yang sifatnya kedinasan, jadi dari dinas mengadakan pelatihan dan kita mengutus beberapa guru PAI dan lainnya. Ada juga pelatihan yang sifatnya umum kami juga mengikuti. Tetapi Sangat disayangkan kalau untuk pelatihan PAI sangat amat jarang. Ada juga pelatihan Tahsin untuk guru dalam meningkatkan kualitas SDM."

Kepala sekolah SD Islam Plus As-Sa'adatain selalu berusaha untuk meningkatkan kualiatas guru dan tenaga kependidikan. Kegiatan yang diadakan ada peningkatan skill dan pelatihan serta worksop, pembinaan yang dilakukan kepala

${ }^{38}$ Wawancara Dengan Kepala Sekolah SD Islam Plus As-Sa'adatain, Umi Yani. Depok, Senin

${ }^{39}$ Wawancara Dengan Kepala Sekolah SD Islam Plus As-Sa'adatain, Umi Yani. Depok, Senin 20 Juli 2020 
Qiro'ah| Jurnal Pendidikan Agama Islam

Vol. 11 No. 1 2021| https://ejurnal.iiq.ac.id/index.php/qiroah P-ISSN: 2085-0115 E-ISSN: 2656-3819

DOI: https://doi.org/10.33511/qiroah.v11n1.76-94
Diterima $\quad: 14$ Mei 2021

Direvisi : 21 Mei2021

Disetujui : 14 Juni 2021

Diterbitkan : 12 Juni 2021

sekolah terhadap bawahan menggunakan dua cara, yaitu secara global untuk semua guru dan staf, ada juga individual sesuai bidang keahliannya.

\section{d. Kegiatan Supervisi}

Peraturan Menteri Pendidikan Nasional Nomor 13 Tahun 2007 telah menetapkan standar kepala sekolah, dalam peraturan tersebut terdapat lima dimensi kompetensi, salah satunya yaitu kompetensi supervisi. Menurut Baharuddin dan Umiarso dalam bukunya menyatakan bahwa salah satu fungsi utama seorang pemimpin menjadi supervisior. Supervisior yaitu orang yang membina, melatih, mendidik, mengawasi, menilai, dan memberi contoh kerja terbaik bagi seluruh anggota organisasi yang dipimpinnya. ${ }^{40}$ Kepala sekolah SD Islam Plus As-Sa'adatain dalam melaksanakan supervisi dilakukan satu tahun dua kali atau satu kali dalam semester, kepala sekolah melaksanakan supervisi dibantu oleh Tim Penjamin Mutu Internal (TPMI).

Setelah dilakukan kegiatan supervisi oleh kepala sekolah, akan ada penilaian dari hasil supervisi atau tindak lanjut, lalu mengevaluasi jika ada kekurangan atau ada yang harus diperbaiki maka akan ada solusi yang membangun untuk meningkatkan kualitas guru. Hal ini senada dengan pernyataan Abi Solekhan guru Pendidikan Agama Islam (PAI), beliau mengatakan bahwa: ${ }^{41}$

"Iya mengadakan supervisi, dan tindak lanjutnya itu mengevaluasi setiap guru, jadi sekiranya guru masih ada kekurangan langsung dikasih solusi yang membangun untuk lebih baik lagi."

Adanya kegiatan supervisi di SD Islam Plus As-Sa'adatain dilakukan rutin dua kali dalam satu tahun, pelaksanaan kegiatan supervisi yang dilakukan oleh kepala sekolah ini salah satunya bertujuan untuk peningkatan kualitas guru.

e. Kegiatan ekstrakurikuler

SD Islam Plus As-Sa'adatain mempunyai kegiatan intrakurikuler dan ekstrakurikuler. Kegiatan intrakurikuler wajib diikuti oleh seluruh siswa, di antaranya KBM meliputi 11 mata pelajaran, conversation, sholat duha dan ta'limul Qur'an, tahfizh, tahsin, muroja'ah dan speech contest, dan pramuka.

Kegiatan ekstrakurikuler merupakan kegiatan siswa di luar kegiatan tambahan di luar KBM. Tujuan kegiatan ekstrakurikuler di SD Islam Plus As-Sa'adatain untuk mengembangkan bakat dan minat siswa. SD Islam Plus As-Sa'adatain mempunyai ekstrakurikuler pilihan, di mana setiap siswa wajib memilih salah satu di antaranya ada melukis, menari, marawis,

\footnotetext{
${ }^{40}$ Baharuddin dan Umiarso, Kepemimpinan Pendidikan Islam, (Yogyakarta: Ar-Ruzz Media, 2014) hlm. 47

${ }^{41}$ Wawancara Dengan Guru Pendidikan Agama Islam (PAI) SD Islam Plus As-Sa'adatain, Abi Solekhan. Depok, Selasa 21 Juli 2020
} 
Qiro'ah| Jurnal Pendidikan Agama Islam

Vol. 11 No. 1 2021| https://ejurnal.iiq.ac.id/index.php/qiroah P-ISSN: 2085-0115 E-ISSN: 2656-3819

DOI: https://doi.org/10.33511/qiroah.v11n1.76-94
Diterima

Direvisi

: 14 Mei 2021

Disetujui

Diterbitkan
: 21 Mei2021

: 14 Juni 2021

: 12 Juni 2021

qiro'ah, futsal, drum band, dan math fun club. Kegiatan ekstrakurikuler berlangsung dari setelah KBM.

Melalui kegiatan ekstrakurikuler siswa mampu mengembangkan potensinya dan meraih prestasi di bidang non akademik.

f. Prestasi Sekolah

Menurut Nur Zazin memaparkan mengenai indikator manajemen mutu terpadu di sekolah penilaian efektifitas output. Output yang diharap, yaitu prestasi sekolah yang dihasilkan oleh proses pembelajaran dan manajemen di sekolah. Output berupa prestasi akademik, juga prestasi non akademik. ${ }^{42}$ Strategi yang dilakukan kepala sekolah dalam meningkatkan mutu pendidikan Islam salah satunya juga dengan membuat program-program yang mendukung dan memfasilitasi siswa dalam mengembangkan potensinya baik dari prestasi akademik dan nonakademik.

Kejuaraan yang sering diraih adalah bidang keIslaman, dibuktikan dengan sekolah yang sudah tiga tahun berturu-turut mengikuti LOKETA (Lomba Keterampilan Agama). Hal ini sesuai dengan pernyataan Umi Yani kepala sekolah, beliau menyatakan bahwa: ${ }^{43}$

"Sudah 3 tahun berturu-turut kita mengikuti Lomba Keterampilan Agama (LOKETA) sampai tingkat provinsi. Ada beberapa kategori lomba seperti MTQ, Adzan, CCQ, MHQ, pidato, sholat berjamah. Kita mengikuti mulai dari tingkat kecamatan kemudian tingkat kota Depok lalu provinsi."

Pada profil sekolah juga sudah disebutkan beberapa prestasi-prestasi yang didapatkan oleh sekolah setiap tahunnya. Hal ini membuktikan bahwa mutu pendidikan Islam di sekolah sudah baik, karena dapat dilihat dari output yang sudah dihasilkan oleh sekolah.

${ }^{42}$ Nur Zazin, Gerakan Menata Mutu Pendidikan, (Jogjakarta: Ar Ruzz Media, 2014) hlm. 170

${ }^{43}$ Wawancara Dengan Kepala Sekolah SD Islam Plus As-Sa'adatain, Umi Yani. Depok, Senin 20 Juli 2020 
Qiro'ah| Jurnal Pendidikan Agama Islam

Vol. 11 No. 1 2021| https://ejurnal.iiq.ac.id/index.php/qiroah P-ISSN: 2085-0115 E-ISSN: 2656-3819

DOI: https://doi.org/10.33511/qiroah.v11n1.76-94
Diterima

Direvisi

Disetujui

Diterbitkan
: 14 Mei 2021

: 21 Mei2021

: 14 Juni 2021

: 12 Juni 2021

\section{KESIMPULAN}

Kepala sekolah SD Islam Plus As-Sa'adatain dalam memecahkan masalah dan mengambil keputusan sudah baik, dan selalu dilakukan dengan musyawarah. Kepala sekolah dalam menggerakkan/ memimpin bawahan (guru, staf, siswa) yaitu kepala sekolah tidak bergantung pada kekuasaan yang formal ketat dan kaku, bersikap santai, tegas, disiplin tidak terlalu formal tetapi tetap bertanggung jawab serta dapat mengayomi serta selalu memberikan contoh terlebih dahulu sebelum memerintah. Selain itu, kepala sekolah selalu berpartisipasi aktif dalam kegiatan yang ada disekolah maupun di luar sekolah. Cara kepala sekolah SD Islam Plus As-Sa'adatain dalam berkomunikasi dengan bawahan (staf, guru dan siswa) yaitu baik, ramah, sopan, santun, hangat, harmonis, tegas, sangat komunikatif, dan berwibawa. Dari uraian di atas dapat disimpulkan bahwa gaya kepemimpinan yang digunakan kepala sekolah SD Islam Plus As-Sa'adatain cenderung kepada gaya kepemimpinan yang Demokratis.

Adapun upaya kepala sekolah dalam meningkatkan mutu pendidikan Islam SD Islam Plus As-Sa'adatain, yaitu: dibentuknya Tim Penjamin Mutu Internal (TPMI), mempunyai kurikulum Islamic Suplementary yang mana di dalamnya membahas pembelajaran pendidikan Islam dan juga pembiasaan adab Islami, untuk meningkatkan kualitas SDM, kepala sekolah mengadakan pelatihanpelatihan secara global pada RAKER awal tahun dan individu sesuai bidang keahliannya, kepala sekolah juga melaksanakan supervisi dengan rutin dua kali dalam satu tahun, dan kepala sekolah dalam meningkatkan mutu pendidikan juga membuat program-program yang mendukung dan memfasilitasi siswa dalam mengembangkan potensinya baik dari prestasi akademik dan nonakademik yang dikemas dalam kegiatan ektrakulikuler. Dari uraian di atas dapat disimpulkan bahwa mutu pendidikan Islam di SD Islam Plus As-Sa'adatain sudah baik, dari perencanaannya, prosesnya dan juga hasilnya.

\section{DAFTAR PUSTAKA}

A.M. Mangunhardjana, SJ. Kepemimpinan. Yogyakarta: Kanisius, 2004.

Arbangi, Dakir, dan Umiarso. Manajemen Mutu Pendidikan. Jakarta: PT Adhitya Andrebina Agung, 2016.

Arifin, Zainal. Penelitian Pendidikan : Metode dan Paradigma Baru. Bandung: PT Remaja Rosdakaya, 2014.

Arifin, Zainal. Penelitian Pendidikan : Metode dan Paradigma Baru. Bandung: PT Remaja Rosdakaya, 2011.

Baharuddin dan Umiarso. Kepemimpinan Pendidikan Islam. Yogyakarta: Ar-Ruzz Media, 2014.

Basri, Hasan. Kepemimpinan Kepala Sekolah. Bandung: Pustaka Setia, 2014.

Daryanto. Kepala Sekolah Sebagai Pemimpin Pembelajaran. Yogyakarta: Gava Media, 2011. 
Qiro'ah| Jurnal Pendidikan Agama Islam

Vol. 11 No. 1 2021| https://ejurnal.iiq.ac.id/index.php/qiroah P-ISSN: 2085-0115 E-ISSN: 2656-3819

DOI: https://doi.org/10.33511/qiroah.v11n1.76-94
Diterima

Direvisi

Disetujui

Diterbitkan
: 14 Mei 2021

: 21 Mei2021

: 14 Juni 2021

: 12 Juni 2021

Pianida, Didi. Kinerja Guru, Kompetensi Guru, Motivasi Kerja, Kepemimpinan Kepala Sekolah. Sukabumi: CV Jejak, 2018.

Hendarman. Revolusi Kinjerja Kepala Sekolah. Jakarta: PT. Indeks, 2015.

Hidayah, Nurul. Kepemimpinan Visioner Kepala Sekolah Dalam Meningkatkan Mutu Pendidikan. Yogyakarta: Ar-Ruzz Media, 2016.

http://lppks.kemdikbud.go.id/id/kabar/kompetensi-dan-kepemimpinan-kepalasekolah/ search pada tanggal 25/07/2020 jam 21.01

Karwati, Euis dan Doni Juni Priansa. Kinerja dan Profesionalisme Kepala Sekolah Membangun Sekolah yang Bermutu. Bandung: Alfabeta, 2013.

M. N. Nasution. Manajemen Mutu Terpadu. Bogor: Ghalia Indonesia, 2005.

Maskawimbang, Jerry H. Supervisi dan Peningkatan Mutu Pendidikan. Bandung: Alfabeta, 2011.

Arif, Muh. Profesi Kependidikan Pedoman dan Acuan Guru Mencintai Profesinya. Gorontalo: Sultan Amai Press, 2012.

Mujib, Abdul. Ilmu Pendidikan Islam. Jakarta: Prenada Media, 2006.

Mulyadi. Kepemimpinan Kepala Sekolah Dalam Mengembangkan Budaya Mutu. Malang: UIN-Maliki Pres, 2010.

Nurkholis. Manajemen Berbasis Sekolah. Jakarta: Grasindo, 2002.

Peraturan Menteri Pendidikan Nasional Republik Indonesia Nomor 13 Tahun 2007.

Peraturan Menteri Pendidikan Nasional Republik Indonesia Nomor 28 Tahun 2010.

Permadi, Dadi. Kepemimpinan Mandiri (Profesional) Kepala Sekolah. Bandung: PT. Sarana Panca Karya Nusa, 2016.

Pianda, Didi. Kinerja Guru, Kompetensi Guru, Motivasi Kerja. Kepemimpinan Kepala Sekolah. Sukabumi: CV Jejak, 2018.

Purwanto, M. Ngalim. Administrasi dan Supervisi Pendidikan. Bandung: PT. Remaja Rosdakarya, 2007.

Rivai, Veithzal. Kepemimpinan dan Perilaku Organisasi. Jakarta: PT. Raja Grafindo, 2004.

Samani, Muclas. Manajemen Sekolah. Yogyakarta: Adicita Karya Nusa, 2009.

Sudaryono. Metodologi Penelitian. Depok: PT Raja Grafindo Persada, 2018.

Sugiono. Metode Penelitian Kualitatif. Bandung: Penerbit Alfabeta, 2020.

Sugiono. Metode Penelitian Pendidikan : Pendekatan Kuantitatif, kualitatif, dan $R \& D$. Bandung: Alfabeta, 2015.

Wahjosumidjo. Kepemimpinan Kepala Sekolah Tinjauan Teoritik dan Permasalahannya. Jakarta: Raja Grafindo Persada, 2010.

Zamza, Firdaus Fakhry. Aplikasi Metodologi Penelitian. Yogyakarta: Deepublish, 2018.

Zazin, Nur. Gerakan Menata Mutu Pendidikan. Jogjakarta: Ar Ruzz Media, 2014. 